\title{
Towards Parliamentarisation of Foreign and Security Policy?
}

Tapio Raunio and Wolfgang Wagner

\begin{abstract}
It is customary to argue that foreign policy is very much dominated by the executive, with parliaments wielding limited influence. However, with the exception of the U.S. Congress, legislative-executive relations in the realm of foreign and security policy have attracted remarkably little scholarly attention. Drawing on a principal-agent framework, this collection scrutinizes the conventional wisdom of 'executive autonomy' in foreign affairs, indicating that even though parliaments have arguably become more involved in foreign and security policy over time, any notions of parliamentarization need to be treated with caution. While expectations of consensus in the name of the national interest continue to play an important role in foreign policy decisionmaking, the papers highlight the role of party-political contestation structuring parliamentary debates and votes in this increasingly politicized issue area. This introductory paper introduces the analytical framework and hypotheses guiding the contributions in this collection, summarizes their main findings and suggests avenues for future research.
\end{abstract}

\section{Key words}

Parliament, government, legislative-executive relations, foreign affairs, security policy

\section{Word count}

7952 
With two notable exceptions, legislative-executive relations in the realm of foreign and security policy have attracted remarkably little scholarly attention. The first is the vast number of studies on the United States Congress whose unparalleled power has made it impossible to ignore in any comprehensive analysis of American foreign policy (Howell and Pevehouse 2007; Milner and Tingley 2015). The other exception is the recent wave of studies on the parliamentary control of military missions that have emerged in the wake of the so-called Democratic Peace debate (e.g. Dieterich et al. 2015; Mello 2014). The study of legislative-executive relations in external relations other than the use of force, however, is by and large unchartered territory for almost every other democratic country other than the United States (Raunio 2014).

Scholarly interest in this topic has been discouraged in at least three ways. First, in contrast to the single remaining superpower (United States), the foreign policies of virtually every other country seem less consequential and naturally attract less scholarly interest. Second, a viable tradition in political theory holds that the role of parliament does and should stop at the 'water's edge' where an area of executive privileges and responsibilities begin. Third, and related to the previous point, traditional notions of dividing labour between the sub-disciplines in political science suggest that comparative politics scholars study legislative-executive relations but stop at the water's edge where the domain of international relations scholars begins whose natural focus is on the relations of the executive with other governments or international organizations. This last point applies certainly more to Europe than to the United States, where there is a rich tradition of examining the influence of domestic actors and institutions on foreign and security policies.

This lack of research is regrettable for several reasons. As suggested above, there is a long line of thinking arguing that foreign and security policy is (and even should be) dominated by the executive, with parliaments wielding marginal or at best limited influence. However, the lack of 
research beyond the very specific case of the U.S. Congress means that we actually do not know whether such 'accepted wisdom' applies to democracies in Europe and other continents. Hence there is a demand for subjecting this notion of 'executive dominance' to careful empirical scrutiny. Considering the stronger impact of regional and global regulations and the ever-growing interdependence of national and international political agendas, scholarly understanding of both parliaments and of legislative-executive relations remains seriously deficient without theory-driven empirical studies on whether and how legislatures become involved in foreign affairs. The expanding range of political issues that are subject to international regulation should produce stronger incentives for parliamentary engagement in foreign affairs, and signals the need to study whether that engagement differs between various policy sectors.

This collection addresses the lack of scholarly attention to national parliaments (other than the U.S. Congress) in foreign and security policy. ${ }^{1} \mathrm{We}$ understand foreign policy as the official external relations of a country, with security policy a key dimension of foreign affairs. The papers included in this collection cover the whole range of foreign policy questions from crisis management and military missions, arms trade, the Common Foreign and Security Policy (CFSP) of the European Union (EU) to international trade and energy agreements. Our guiding question goes to the very heart of legislative-executive relations: which factors allow parliaments to exercise influence over the executive and, by implication, under which circumstances does the executive succeed in maintaining or re-capturing executive privilege? We also explore whether legislatures have become more involved in foreign affairs over time. The second main research question focuses on the party politics of foreign affairs: which political forces inside the legislature act as engines for tighter oversight of the government? In this context we examine the respective roles of party ideology and country-specific historical or constitutional features in explaining the level of parliamentary engagement. The next section reviews the state of the art on executive-legislative relations in 
foreign and security policy. Based on principal-agent models, the third section introduces our analytical framework and research hypotheses. The two final sections of this introductory paper discuss the main findings and their implications for future research.

\section{The State of the Art: Weak Parliaments, Strong Executives, and the Changing Foreign Policy}

\section{Agenda}

It is customary to argue that foreign policy is very much dominated by the executive, with parliaments weaker vis-à-vis the government in foreign policy than in domestic matters ${ }^{2}$-- and indeed, such bias in favour of the government is even perceived to benefit the country. ${ }^{3}$ This line of thinking is nothing new, and can be traced back to political philosophers such as Locke (1960) or de Tocqueville (1990).

The notion of 'executive dominance' can be best captured through comparing foreign affairs with domestic and EU policies (Hegeland 2007; Lüddecke 2010). Domestic and EU laws are processed in parliaments according to standard practices familiar to MPs, whereas foreign policy consists to a large degree of non-legislative items such as monitoring international negotiations or military conflicts. The information rights of legislatures can also be stronger in domestic and EU issues. Information asymmetries in favour of the executive that represents the country abroad are thus significant, even in those instances where the approval of the legislatures is required for the agreements reached by the governments. ${ }^{4}$ Differences are also found in policy-making style and level of contestation. In domestic issues party-political conflicts and public discussion are seen as normal or prerequisite for democratic deliberation, whereas foreign policy decision-makers often evoke notions of national unity and demand that the major political parties at least try to build consensus on these issues so that disunity at home does not undermine success abroad. This is 
indeed the core of the 'politics stops at the water's edge' idiom, according to which ideological differences are set aside in favour of national interest.

Such considerations apply particularly to security and military issues. The effective formulation and defence of national interest requires that the executive is given sufficient room for manoeuvre, and secrecy is often presented as integral to the advancement of national interests. As the efficient conduct of security policy, especially regarding use of force, requires flexibility and fast reactive capacity, parliamentary involvement may cause unnecessary delays that obstruct the achievement of important foreign policy goals. Members of parliament (MP) themselves may share the belief that public criticism of the government might compromise national security. Delegation to the executive can also be attractive for MPs as foreign relations are perhaps not that important for re-election and even with active scrutiny, it is the executive that gets the blame or credit for success abroad. There can thus be more costs than benefits for legislators in subjecting the government to tight scrutiny in foreign relations.

Governments can indeed seek to avoid legislative constraints through framing issues as security threats - in line with what is termed 'securitization' in international relations literature (Waever 1995; Buzan et al. 1998). In the United States presidents can benefit from framing foreign policy issues as security or military matters or from employing the rhetoric of war in other issue areas such as fighting drugs. During wars presidents enjoy not only more discretion but also greater success in navigating policies through the Congress, and budgetary items with more direct connections to national security allow the president greater freedom from Congressional constraints than foreign trade and aid, in which decision-making is shaped more by constituency interests and party-political differences (e.g. Hiscox 2002; Milner and Judkins 2004; Broz 2011; Howell et al. 2013; Milner and Tingley 2015). However, comparing the impact of the 'war on terror' on the legislative-executive 
relationship in eight countries, the volume edited by Owens and Pelizzo (2009; see also Scott and Carter 2014) suggests that parliaments are not necessarily weakened during such crisis, with only three cases — the United States, Great Britain and Russia — providing evidence of executive empowerment.

At least the U.S. Congress has been fighting back. Since the Vietnam War it has clearly become more assertive in foreign affairs, with Congressional influence on average stronger under divided government. For example, it has introduced stricter reporting requirements that force the president to consult Congress prior to decision-making or during international economic negotiations and military conflicts, the most famous being the contested War Powers Resolution from $1973 .{ }^{5}$ The literature on the Congress also shows the variety of tools legislators have for engaging in foreign policy - from plenary debates and questions, committee scrutiny, voting on budgetary items and international agreements, setting tighter ex ante limits to presidential action, exercising direct control over the military, to public posturing and grandstanding (e.g. Lindsay 1994; Howell and Pevehouse 2007; Carter and Scott 2009; Kriner 2010; Auerswald and Campbell 2012; Howell et al. 2013; Campbell and Auerswald 2015; Milner and Tingley 2015).

Apart from Lüddecke (2010), who provides an in-depth overview of German Bundestag, the British House of Commons and the Danish Folketinget, scholarly understanding of how European legislatures engage in foreign affairs is very limited. Recent studies of parliamentary control of CFSP indicate strong variation between legislatures (Peters et al. 2008; Huff 2015). Otherwise comparative research has almost exclusively focused on 'war powers'. This body of work underlines the importance of historical experiences, such as wars, on structuring the constitutional framework for foreign policy, including parliamentary participation rights (Cassese 1980). It also provides support for the 'parliamentary peace' argument according to which involvement in 
military conflicts decreases the stronger the war powers of the respective national legislatures. Negative war experiences and lower levels of security threats correlate with parliamentary veto power over troop deployments. On the other hand, joint military missions, coordinated primarily by North Atlantic Treaty Organization (NATO), the United Nations (UN), and the EU, or collective defence clauses create challenges for parliamentary involvement. ${ }^{6}$ In the context of accession to NATO and the EU, many Central and Eastern European states relaxed their parliamentary restrictions and abolished their parliamentary provisos for NATO and EU operations. These studies also indicate that decisions about entering military missions can be much more politicized and contested than during the Cold War (e.g. Born and Hänggi 2004; Peters and Wagner 2011; 2014; Auerswald and Saideman 2014; Mello 2014; Dieterich et al. 2015).

However, whether to participate in military operations is just one, although highly important, aspect of foreign policy. This is where the changing nature of foreign policy enters into the equation. Previously one could more plausibly argue that international issues were significantly less relevant for MPs and voters, thus reducing incentives for parliamentary engagement. Already in the late 1970s, however, Manning (1977) paid attention to the rise of issues falling somewhere between pure foreign and domestic policy — or what he referred to as 'intermestic' issues. Growing levels of interdependence and globalization have internationalized an increasing range of issues previously decided nationally, such as immigration (as exemplified by the current refugee crisis in Europe), trade, energy, and environment policies or human rights questions. Not only are more issues decided in or influenced by European or international negotiations, they also have more direct distributional consequences for voters and interest groups. Moreover, higher levels of education and more varied sources of information have brought about a comparably well-informed and interested public that pays more attention to international questions (Norris 2011), with the politicization of international relations (Zürn 2014) thus providing an increasing 'electoral connection' to foreign 
affairs (Aldrich et al. 2006). The changes in the international system also facilitate broader interest and debate in foreign and security policy. In the post-Cold War era countries have more choice. Decisions about entering 'wars of choice' (see above), exporting arms, development aid or trade agreements are thus likely to be more politicized decisions than during the Cold War. These developments should produce stronger incentives for parliamentary engagement in foreign affairs whilst bringing domestic, European and international politics closer together.

Turning to parliamentary culture in foreign affairs, the 'politics stops at the water's edge' thesis suggests that consensus is the norm or goal, particularly in security and military matters. In a rare study from the European context, Jerneck et al. (1988) showed that while foreign and security policy were characterized by consensus in the Swedish Riksdag, foreign aid and to a lesser extent general defence policy (which has often strong constituency links, for example through decisions on location of domestic military bases) produced conflict in the committees. Yet there is room for party politics and government-opposition dialogue, although apparently less than in domestic policy. In foreign policy 'hawks' are more often found among right-leaning legislators and 'doves' on the left. In the U.S. context there is strong evidence of such a divide between Democrats and Republicans (e.g. Poole and Rosenthal 1991; Alesina and Rosenthal 1995), although party composition of the government does not seem to have any discernible effect on American use of force abroad (Gowa 1998). However, examining eighteen parliamentary democracies during the Cold War, Palmer et al. (2004) find that right-wing governments are more likely to be involved in militarized disputes than leftist governments. For the period 1960-1996, Arena and Palmer (2009) find that right-wing governments are more likely to initiate them - a finding confirmed by Clare (2010). Examining British, French and German responses to conflicts in Bosnia and Kosovo and to the development of EU's military capacity, Rathbun (2004) showed that leftist parties were more likely to believe in multilateral cooperation and utilized a broader conception of the national interest that included the 
promotion of human rights. Right-wing parties, in turn, were more likely to believe in military responses. Other studies also provide evidence of centre-right parties being more supportive of military operations, such as joining the 'coalition of the willing' in the Iraq War or the operation in Afghanistan (e.g. Schuster and Maier 2006; Auerswald and Saideman 2014; Mello 2014). ${ }^{7}$

\section{Analytical Framework and Research Hypotheses}

The study of legislative-executive relations is interested in the balance of power between the parliament and the government, and the ways in which the former can control or influence the executive. This literature is often couched in terms of 'parliamentarization' or - more frequently 'de-parliamentarization', with the latter particularly pronounced in research about parliamentary involvement in EU and global governance. Instead of privileging or even endorsing one view over the other, we suggest conceiving of legislative-executive relations as a continuous process of (re)calibration of powers and competences in response to developments within the political system, on the one hand, and in a state's international environment on the other hand.

We use principal-agent (PA) framework for capturing the dynamics of legislative-executive relations. PA models are recognized as highly useful for analyzing the ways in which the parliament (principal) can control the government (agent) (e.g. Strøm 2000; Huber and Shipan 2002; Strøm et al. 2003; Shugart 2006; Martin et al. 2014). Its core assumption - that the agent can have interests systematically different from the principal - is particularly applicable to foreign affairs. The executive is more susceptible to the demands and pressures of the international environment and other executives whereas the legislature 'stays home' and MPs are likely to emphasize more the need to align foreign policies with the preferences of the citizens. Indeed, a standard argument in the literature on the United States is that the president tends to be more internationalist, preferring more extensive foreign engagement while legislators, representing geographically small 
constituencies, are more parochial in their outlook (Milner and Tingley 2015). Given the informational asymmetries inherent in foreign policy and international bargaining, the main challenge for the parliament is to make sure the executive does not misuse its degree of autonomy. The same goes for the fundamental logic of PA interactions according to which the principal is happy to grant discretion to the agent as long as this relieves the principal of the burden to invest the necessary resources itself. However, the principal is assumed to be alert to the possibility that the agent privileges its own interest over that of the principal and is prepared to take action in order to reduce 'agency slack' or 'slippage'. Thus, PA framework captures cases of both executive dominance and of tight legislative control.

PA models have been applied extensively to studying the presidential checks-and-balances system of the United States, including relations between the Congress and the federal government (Miller 2005; Gailmard 2014). In parliamentary regimes the chain of delegation is much simpler, with cabinet survival depending on the confidence of the legislature. Therefore this regime type is characterized by a fusion of powers and interests between the cabinet and its party groups in the legislature and a strong party discipline (King 1976). However, while our central research question focuses on relations between the legislature and the executive, we do not treat the former as a unitary actor. Instead, we approach parliaments as party-political institutions where political parties and individual MPs have different motives and opportunities for influencing foreign policy. Here we pay particular attention to party ideology without neglecting government-opposition dynamics. Party strategy can prioritize office-seeking, policy-seeking, or vote-seeking considerations (Strøm 1990; Müller and Strøm 1999), and these can have different implications for overall legislative behaviour and for how both the governing and opposition parties approach foreign policy issues. In terms of cohesion, even in the case of single-party majority cabinets (like those normally in the United Kingdom), lack of unity inside the ruling party may act as a significant constraint on the 
prime minister and her government. And under multi-party coalition cabinets, the norm in European democracies, the coalition partners most likely have different preferences also over foreign policy (e.g. Rathbun 2004; Kaarbo 2012). In such cases the parliamentary groups of the governing parties, particularly those of the junior parties in the cabinet, have stronger incentives to curb executive discretion (e.g. Müller and Strøm 2000; Strøm et al. 2008; Strøm et al. 2010; Martin and Vanberg 2011).

Drawing on these insights from PA theory and on the empirical research outlined in the previous section, the contributions in this collection focus on the following four hypotheses:

H1: Legislatures do not acquiesce in leaving foreign affairs to the executive. Conventional wisdom of 'executive autonomy' in foreign affairs suggests that legislatures accept the delegation of authority to the government. In contrast, we hypothesize that legislatures monitor executive actions and strive for a recalibration of executive-legislative relations by investing into oversight and scrutiny. However, instead of assuming a general trend towards parliamentarization, we expect that the level of autonomy granted to the executive varies depending on developments within the political system, on the one hand, and in a state's international environment on the other hand. Whereas this first hypothesis operates on a rather general level, the following hypotheses examine the specific driving forces and contextual conditions under which legislatures take action and executive-legislative relations are recalibrated.

H2: Tighter legislative oversight is triggered by lack of trust in the government. This lack of trust can have two basic sources. First, it can simply result from preference divergence between the parliamentary majority and the government - or from coalition parties wanting to keep tabs on one another. Second, it can follow executive failure in foreign policy which includes both the 
government's inability to achieve political aims and, more frequently, its unwillingness to comply with the rules and procedures set by the principal. Examples of the former include failed or at least highly contested military missions such as the divisive experience of the Vietnam War which was crucial in bringing about the War Powers Resolution and overall more assertive Congressional behaviour in foreign policy, while the latter includes (secret) arms exports to country which a parliament explicitly blacklisted (Bauer 2004). Doubts about the agent's trustworthiness should lead to stricter reporting requirements and stronger ex ante control mechanisms.

H3: The powers of the executive should grow in response to external threats or hostilities. In line with the securitization thesis, parliamentary engagement can be influenced by how issues are viewed domestically. Research on the U.S. demonstrates that the executive has benefitted from framing foreign policy issues as security or military matters, and a similar logic can be expected to work in favour of the executive also elsewhere. More broadly, historians of state-building have identified external threats and hostilities as main driving forces of executive empowerment (Tilly 1975). We therefore expect a re-calibration of powers and competences in favour of the executive when the international environment turns more threatening and foreign policy issues are successfully securitized. Here it must be emphasized that we do not expect to see any real weakening of parliamentary legal authority. Instead, the empowerment of the executive should primarily result from the government pushing for faster decision-making processes and cross-party consensus, with the MPs themselves perhaps sharing this concern for political unity and expedited or lighter parliamentary involvement. When dangers gather, it is not appropriate to criticize the executive.

H4: Left-wing parties are more eager to strengthen the legislature vis-à-vis the executive. Previous research has demonstrated that left-wing parties are more 'dovish', 'inclusive' and 'internationalist' 
whereas right-wing parties are more 'hawkish', 'militarist' and 'nationalist'. Because decisionmaking procedures impact on substantial policies, we extend this reasoning to party-political contestation over the role of the parliament in foreign policy. We thus expect left-wing parties to be more in favour of overall broader domestic participation and particularly strong parliamentary oversight of foreign policy in order to prevent 'agency slack', whereas right-wing parties are more prepared to grant the executive more autonomy in pursuing the national interest.

\section{Main Findings}

The contributions in this collection paint a very nuanced and detailed picture of parliamentary engagement in foreign affairs. Overall, the findings support our hypotheses, but cross-national patterns and developments need to be understood against the backdrop of country-specific explanatory variables. More than in domestic or EU issues, foreign and security policy are areas where factors related to national history and geopolitics shape both the constitutional and political framework for parliamentary engagement and the level of public party-political contestation over policies.

In line with our first hypothesis, the contributions to this collection show that legislatures generally find ways to subject governments to tighter oversight in foreign and security policy. However, while the papers point in the direction of stronger parliamentary engagement, any notions of 'parliamentarization' in this field must be treated with extreme caution. Even those legislatures vested with strong constitutional rights face the problem of information asymmetry, and indeed much of parliamentary activity focuses on getting timely and accurate information. What is comforting though is the willingness of MPs and political parties to keep demanding for such information and to publicly challenge the executive even in hard security choices such as troop 
deployments. Here the question is not necessarily so much about the influence of the parliament what matters perhaps more is that the legislature provides a forum for debate where the decisions are justified and explained (Lord 2011).

Importantly, many of the papers in this collection suggest that MPs themselves acknowledge what they perceive as appropriate limits to parliamentary engagement. The case study of France by Ostermann (2017) is most revealing in this respect, with French parliamentarians recognizing that while stronger constitutional rights for Assemblée nationale and the Sénat are positive developments, actual leadership in foreign affairs belongs firmly to the executive. While the French attitudes reflect both the semi-presidential regime and the tradition of presidential dominance, the papers by Mello (2017), Wagner et al. (2017), and Sakaki and Lukner (2017) provide evidence of similar balancing between legislative scrutiny and executive autonomy in several other countries. In the House of Commons, in particular, there is a yet-to-be-resolved discussion about whether the approval of the chamber should be required for dispatching British soldiers to military missions, with significant variation among MPs over the issue regardless of their party affiliation.

Challenges apply also to CFSP and EU trade policy. Recent work on parliamentary scrutiny of EU affairs has provided consistent evidence of legislatures gradually learning how to be more effectively involved in European governance, particularly through subjecting their governments to tighter scrutiny before decisions are taken in Brussels (e.g. Winzen 2013; Auel and Christiansen 2015; Hefftler et al. 2015). Nonetheless, strong differences remain between parliaments, and trade policy and CFSP may be particularly troublesome policy areas for domestic legislatures. Trade policy falls under the competence of the EU, with the Commission negotiating on behalf of the Union even when national parliaments possess veto power over the agreements. As Jančić (2017) shows, the multi-level system of the EU presents national legislatures with its own set of 
challenges, not least concerning information flows, while the degree of parliamentary input may well depend increasingly on direct links with EU institutions and on interparliamentary cooperation. The paper by Herbel (2017), in turn, indicates that most CFSP issues escape national parliamentary scrutiny. However, there are good grounds for arguing that more active parliamentary scrutiny of EU level foreign policy processes should not be too difficult to achieve. Martin (2000: 201) makes the interesting observation that the executive may try to evade or manages to avoid legislative constraints in one-off situations, whereas parliamentary engagement will be more institutionalized in stable and repeated forms of international cooperation. Ex ante control of Council and European Council meetings is already well established in select national parliaments, for example through ministerial hearings in committees, and hence procedures for systematic scrutiny of CFSP and trade questions already exist (Huff 2015; Raunio 2016).

The observed trend towards stronger oversight is - in line with our second hypothesis - to a large extent explained by lack of trust in the executive. As in domestic politics, ideological differences between the government and the opposition as well as lack of cohesion inside the cabinet produce tighter scrutiny and contestation, but in foreign affairs policy failures have resulted in legal and procedural reforms that reduce the autonomy of the executive. The paper by Kaarbo and Kenealy (2017) illuminates the role of 'institutional memory' or 'historical analogies', with legislatures and MPs drawing conclusions from past mistakes. Previous research on the U.S. Congress, and the paper by Auerswald (2017) establish clear causal relationships between military failures abroad and more stringent Congressional checks on the president and the military. In the United Kingdom and Spain the divisive experience of the Iraq War in 2003 brought about changes to parliamentary war powers, with the Cortes now enjoying veto over troop dispatches and votes in the House of Commons before the country takes part in military conflicts. 
The impact of any 'securitization' strategies is more difficult to gauge (H3). While actual conduct of military operations is understandably delegated to the executive, issues related to national security clearly attract a lot of attention from MPs across the political spectrum. And, as the paper by Lagassé and Saideman (2017) illustrates, when things go awry abroad during a conflict, MPs do not hesitate to demand explanations from the government. In Japan political elites widely concur that their country has faced an increasingly volatile security environment, and according to Sakaki and Lukner this has resulted in faster decision processes and more cross-party consensus, the side effect of which is more leeway for the cabinet. Herranz-Surrallés (2017) in turn shows in her paper on international energy agreements that securitization attempts by the executive failed, triggering instead politicization and stronger parliamentary scrutiny. As outlined in the second section of this introductory paper, research on the U.S. Congress has found clear support for the securitization thesis, with presidents subject to looser legislative constraints when issues are framed as security threats, but it might be that the specific foreign policy context of the United States, especially after 9/11 terrorist attacks, contributes to these findings.

The papers provide consistent support for our hypothesis about the impact of ideology, with left-ofcentre parties more interested in curbing executive autonomy (H4). The comparative study of Wagner et al. (2016) shows that right-wing parties, radical right excluded, supported military missions and an unconstrained executive, whereas social democratic, radical left and green parties were against the missions and more in favour of setting parliamentary constraints on the government. More detailed country studies, including Japan, reveal a clear pattern: left-wing MPs and political parties were behind much of the parliamentary activity, demanding more information, putting questions to the ministers, or tabling motions that strengthen the legislature vis-à-vis the executive. However, the impact of party ideology is nonetheless moderated by country-specific 
factors, such as the nation's past experiences or geopolitics, which impact on policy choices and on the nature of debates.

\section{Agenda for Future Research}

Our findings should be viewed primarily as starting points for future research. The papers in this collection provide interesting insights into legislative-executive relations in foreign and security policy, but there is clearly space, and the need, for more systematic data collection. There are at least four areas that appear particularly relevant for both parliamentary and foreign policy scholars.

First, the interdependence of domestic, European and global political agendas and the politicization of international relations should increase the 'electoral connection' in foreign affairs. If this is the case, we should also see higher incentives for individual MPs to engage in foreign and security policy. Research on the U.S. Congress has identified foreign policy 'entrepreneurs' (Carter \& Scott 2009), and future research could analyze assignments to foreign policy-related committees or plenary speeches and questions to establish variation among representatives (e.g. Martin 2013; Rozenberg et al. 2011; 2015). The findings in this collection certainly point in the direction of more assertive parliamentary behaviour, with MPs not content to leave matters to the ministers or generals.

The second issue warranting more systematic research is the use of various control instruments. The papers in this collection show that parliaments use a broad set of mechanisms to oversee the government in foreign affairs. Essentially the toolkit appears the same as in domestic matters, ranging from committee scrutiny to parliamentary questions and plenary speeches and votes. It is nonetheless clear that ex ante instruments are even more crucial than in the context of national legislation where parliaments can amend draft bills and often are also involved in the transposition 
stage. Whether to deploy troops to a military conflict or scrutinizing the bargaining position of the executive ahead of European or global negotiations, on the other hand, are clearly questions where parliamentary influence needs to be exerted beforehand. And as the paper by Lagassé and Saideman (2017) and previous research on the U.S. Congress show, parliamentary control of on-going military operations is wrought with practical difficulties, not least regarding access to classified information. A specific ex ante instrument for potential parliamentary influence is the 'grand strategy' document. In foreign affairs the government programme is often not the most important document guiding executive action. Countries throughout the world, as well as NATO and the EU, have adopted 'grand strategies' that outline the core objectives and issues in foreign and security policy. A good example is Finland, where the Eduskunta and political parties are actively involved in the formulation of the Government Security and Defence Policy Report published roughly every four years (Raunio 2016). As these documents set the parameters for subsequent decision-making, the question whether legislatures are involved in drafting and approving them becomes all the more important.

Furthermore, the explanatory power of the left-right dimension signals the need to pay more attention to domestic sources of national foreign policies. In Europe international relations scholars still primarily explain national foreign and security policies through focusing on countries' economic or geopolitical interests, thus neglecting the different positions of political parties and other relevant actors. This stands in striking contrast to the United States, where scholars have systematically analyzed the party-political dynamics of foreign policy, not least through examining the voting behaviour of the representatives. Future research should also focus more on variation between different types of foreign policy questions, both in terms of party positions and of modes of parliamentary engagement. For example, does trade policy produce different coalitions than security policy as research on the U.S. Congress and select other legislatures suggests. 
Finally, the effects of parliamentary involvement require further examination. Legislative constraints such as veto rights can on their own influence the position of the executive, but especially in parliamentary regimes the independent impact of the legislature may often be difficult to distinguish from other explanatory variables. For example, studies in the wake of the Democratic Peace debate suggest that parliamentary ex ante veto power impacts on the propensity of governments to use armed force. Yet the evidence can be unclear as Dieterich, Hummel and Marschall (2015) do not control for additional influences such as military capabilities and Mello (2014) finds evidence in some but not all cases. Beyond military missions, the impact of the legislature on the position of government on trade agreements, arms exports, sanctions or development aid is by and large unchartered territory. The influence of the parliament can also be more indirect. Plenary debates can act as a brake or a moderating force on the executive, especially when there are political parties offering alternatives and a healthy media covering the debates (Baum and Potter 2015). Another avenue worth exploring is whether legislatures through interparliamentary assemblies and other networks influence the behaviour of either individual governments or international organisations.

\section{References}

Aldrich, John H., Gelpi, Christopher, Feaver, Peter, Reifler, Jason, and Sharp, Kristin Thompson (2006). 'Foreign Policy and the Electoral Connection', Annual Review of Political Science, 9, 477502.

Alesina, Alberto, and Rosenthal, Howard (1995). Partisan Politics, Divided Government and the Economy. Cambridge: Cambridge University Press. 
Arena, Philip, and Palmer, Glenn (2009). 'Politics or the Economy? Domestic Correlates of Dispute Involvement in Developed Democracies', International Studies Quarterly, 53:4, 955-75.

Auel, Katrin, and Christiansen, Thomas, eds. (2015). After Lisbon: National Parliaments in the European Union. West European Politics, 38:2.

Auerswald, David (2017). Legislatures and Civil-Military Relations in the U.S. and U.K., West European Politics.

Auerswald, David P., and Campbell, Colton C., eds. (2012). Congress and the Politics of National Security. New York: Cambridge University Press.

Auerswald, David P., and Saideman, Stephen M. (2014). NATO in Afghanistan: Fighting Together, Fighting Alone. Princeton: Princeton University Press.

Bauer, Sibylle (2004). 'The role of parliaments in European arms export policy', in Jocelyn Mawdsley, Marta Martinelli, and Eric Remacle (eds.), Europe and the Global Arms Agenda: Security, Trade and Accountability. Baden-Baden: Nomos, 137-47.

Baum, Matthew A., and Potter, Philip B.K. (2015). War and Democratic Constraint: How the Public Influences Foreign Policy. Princeton: Princeton University Press.

Beasley, Ryan K., and Kaarbo, Juliet (2014). 'Explaining Extremity in the Foreign Policies of Parliamentary Democracies', International Studies Quarterly, 58:4, 729-40. 
Born, Hans, and Hänggi, Heiner, eds. (2004). The 'Double Democratic Deficit': Parliamentary Accountability and the Use of Force Under International Auspices. Aldershot: Ashgate.

Broz, J. Lawrence (2011). 'The United States Congress and IMF financing, 1944-2009', Review of International Organizations, 6:3, 341-68.

Buzan, Barry, Waever, Ole, and de Wilde, Jaap (1998). Security: A Framework for Analysis. Boulder, CO: Lynne Rienner.

Campbell, Colton C., and Auerswald, David P., eds. (2015). Congress and Civil-Military Relations. Washington D.C.: Georgetown University Press.

Carter, Ralph G., and Scott, James M. (2009). Choosing to Lead: Understanding Congressional Foreign Policy Entrepreneurs. Durham, NC: Duke University Press.

Cassese, Antonio, ed. (1980). Parliamentary Control over Foreign Policy: Legal Essays. Alphen aan den Rijn: Sijthoff \& Noordhoff.

Clare, Joe (2010). 'Ideological Fractionalization and the International Conflict Behavior of Parliamentary Democracies', International Studies Quarterly, 54:4, 965-87.

Costa, Olivier, Dri, Clarissa, and Stavridis Stelios, eds. (2013). Parliamentary Dimensions of Regionalization and Globalization: The Role of Inter-parliamentary Institutions. Basingstoke: Palgrave Macmillan. 
Crum, Ben, and Fossum, John E., eds. (2013). Practices of Inter-Parliamentary Coordination in International Politics: The European Union and beyond. Colchester: ECPR Press.

de Tocqueville, Alexis (1990) [1835/1840]. Democracy in America, Vol. I. New York: Vintage Books.

Dieterich, Sandra, Hummel, Hartwig, and Marschall, Stefan (2015). 'Bringing democracy back in: The democratic peace, parliamentary war powers and European participation in the 2003 Iraq War', Cooperation and Conflict, 50:1, 87-106.

Evans, Peter B., Jacobson, Harold K., and Putnam, Robert D., eds. (1993). Double-Edged Diplomacy: International Bargaining and Domestic Politics. Berkeley: University of California Press.

Gailmard, Sean (2014). 'Accountability and Principal-Agent Theory', in Mark Bovens, Robert E. Goodin, and Thomas Schillemans (eds.), The Oxford Handbook of Public Accountability. Oxford: Oxford University Press, 90-105.

Gowa, Joanne (1998). 'Politics at the Water's Edge: Parties, Voters, and the Use of Force Abroad', International Organization, 52:2, 307-24.

Hefftler, Claudia, Neuhold, Christine, Rozenberg, Olivier, and Smith, Julie, eds. (2015). The Palgrave Handbook of National Parliaments and the European Union. Basingstoke: Palgrave Macmillan. 
Hegeland, Hans (2007). 'The European Union in national parliaments: domestic or foreign policy? A study of Nordic parliamentary systems', in John O'Brennan and Tapio Raunio (eds.), National Parliaments within the Enlarged European Union: From 'victims' of integration to competitive actors? Abingdon: Routledge, 95-115.

Herbel, Annika (2017). 'Parliamentary Scrutiny of the EU's Common Foreign and Security Policy', West European Politics.

Herranz-Surrallés, Anna (2014). 'The EU's Multilevel Parliamentary (Battle)Field: Interparliamentary Cooperation and Conflict in Foreign and Security Policy', West European Politics, $37: 5,957-75$.

Herranz-Surrallés, Anna (2017). 'Energy Diplomacy under Scrutiny: Parliamentary Control of Intergovernmental Agreements with Third-Country Suppliers', West European Politics.

Hiscox, Michael J. (2002). International Trade and Political Conflict: Commerce, Coalitions, and Mobility. Princeton: Princeton University Press.

Howell, William G., Jackman, Saul P., and Rogowski, Jon C. (2013). The Wartime President: Executive Influence and the Nationalizing Politics of Threat. Chicago: The University of Chicago Press.

Howell, William G., and Pevehouse, Jon C. (2007). While dangers gather: Congressional Checks on Presidential War Powers. Princeton: Princeton University Press. 
Huber, John D., and Shipan, Charles R. (2002). Deliberate Discretion? Institutional Foundations of Bureaucratic Autonomy. Cambridge: Cambridge University Press.

Huff, Ariella (2015). 'Executive Privilege Reaffirmed? Parliamentary Scrutiny of the CFSP and CSDP‘, West European Politics, 38:2, 396-415.

Jančić, Davor (2017). 'TTIP and Legislative-Executive Relations in EU Trade Policy', West European Politics.

Jerneck, Magnus, Sannerstedt, Anders, and Sjölin, Mats (1988). 'Internationalization and Parliamentary Decision-Making: The Case of Sweden 1970-1985', Scandinavian Political Studies, $11: 3,169-94$.

Kaarbo, Juliet (2012). Coalition Politics and Cabinet Decision Making: A Comparative Analysis of Foreign Policy Choices. Ann Arbor: University of Michigan Press.

Kaarbo, Juliet and Daniel Kenealy (2017). 'Precedents, Parliaments, and Foreign Policy: Historical Analogy in the House of Commons Vote on Syria', West European Politics,

Kesgin, Baris, and Kaarbo, Juliet (2010). 'When and How Parliaments Influence Foreign Policy: The Case of Turkey's Iraq Decision', International Studies Perspectives, 11:1, 19-36.

King, Anthony (1976). 'Modes of Executive-Legislative Relations: Great Britain, France, and West Germany', Legislative Studies Quarterly, 1:1, 37-65. 
Kriner, Douglas L. (2010). After the Rubicon: Congress, Presidents, and the Politics of Waging War. Chicago: University of Chicago Press.

Lagassé, Philippe and Stephen Saideman (2017). 'Public Critic or Secretive Monitor: Party Objectives and Legislative Oversight of the Military in Canada', West European Politics.

Lindsay, James M. (1994). Congress and the Politics of U.S. Foreign Policy. Baltimore: Johns Hopkins University Press.

Locke, John (1960) [1690]. Two Treatises of Government. Cambridge: Cambridge University Press.

Lord, Christopher (2011). 'The political theory and practice of parliamentary participation in the Common Security and Defence Policy', Journal of European Public Policy, 18:8, 1133-50.

Lüddecke, René (2010). Parlamentarisierung der nationalen Außenpolitik. Baden-Baden: Nomos.

Manning, Bayless (1977). 'The Congress, the Executive and Intermestic Affairs: Three Proposals', Foreign Affairs, 55:2, 306-24.

Mansfield, Edward D., and Milner, Helen V. (2012). Votes, Vetoes, and the Political Economy of International Trade Agreements. Princeton: Princeton University Press.

Martin, Lisa L. (2000). Democratic Commitments: Legislatures and International Cooperation. Princeton: Princeton University Press. 
Martin, Lanny W., and Vanberg, Georg (2011). Parliaments and Coalitions: The Role of Legislative Institutions in Multiparty Governance. Oxford: Oxford University Press.

Martin, Shane (2013). 'Is All Politics Local? The Role-orientation of Irish Parliamentarians towards Foreign Policy’, Irish Political Studies, 28:1, 114-29.

Martin, Shane, Saalfeld, Thomas, and Strøm, Kaare W., eds. (2014). The Oxford Handbook of Legislative Studies. Oxford: Oxford University Press.

Mello, Patrick A. (2014). Democratic Participation in Armed Conflict: Military Involvement in Kosovo, Afghanistan and Iraq. Basingstoke: Palgrave Macmillan.

Mello, Patrick (2017). 'Curbing the Royal Prerogative to Use Military Force: The British House of Commons and the Conflicts in Libya and Syria', West European Politics.

Miller, Gary J. (2005). 'The Political Evolution of Principal-Agent Models', Annual Review of Political Science, 8, 203-25.

Milner, Helen V. (1997). Interests, Institutions, and Information: Domestic Politics and International Relations. Princeton: Princeton University Press.

Milner, Helen V., and Judkins, Benjamin (2004). 'Partisanship, Trade Policy, and Globalization: Is There a Left-Right Divide on Trade Policy', International Studies Quarterly, 48:1, 95-119. 
Milner, Helen V., and Tingley, Dustin (2015). Sailing the Water's Edge: The Domestic Politics of American Foreign Policy. Princeton: Princeton University Press.

Müller, Wolfgang C., and Strøm, Kaare, eds. (1999). Policy, Office, or Votes? How Political Parties in Western Europe Make Hard Decisions. Cambridge: Cambridge University Press.

Müller, Wolfgang C., and Strøm, Kaare, eds. (2000). Coalition Governments in Western Europe. Oxford: Oxford University Press.

Norris, Pippa (2011). Democratic Deficit: Critical Citizens Revisited. Cambridge: Cambridge University Press.

Ostermann, Falk (2017). 'France's Reluctant Parliamentarization of Military Deployments. The 2008 Constitutional Reform in Practice', West European Politics.

Owens, John E., and Pelizzo, Ricardo, eds. (2009). 'The Impact of the Post-9/11 'War on Terror' on Executive-Legislative Relations: A Global Perspective', Journal of Legislative Studies, 15:2-3.

Pahre, Robert, ed. (2006). Democratic Foreign Policy Making: Problems of Divided Government and International Cooperation. Basingstoke: Palgrave Macmillan.

Palmer, Glenn, London, Tamar and Regan, Patrick (2004). 'What's Stopping You? The Sources of Political Constraints on International Conflict Behavior in Parliamentary Democracies', International Interactions, 30:1, 1-24. 
Peters, Dirk, and Wagner, Wolfgang (2011). 'Between Military Efficiency and Democratic Legitimacy: Mapping Parliamentary War Powers in Contemporary Democracies, 1989-2004', Parliamentary Affairs, 64:1, 175-92.

Peters, Dirk, and Wagner, Wolfgang (2014). 'Executive Privilege or Parliamentary Proviso? Exploring the Sources of Parliamentary War Powers', Armed Forces \& Society, 40:2, 310-31.

Peters, Dirk, Wagner, Wolfgang, and Deitelhoff, Nicole, eds. (2008). The Parliamentary Control of European Security Policy. Oslo: ARENA Report No 7/08.

Poole, Keith T., and Rosenthal, Howard (1991). 'Patterns of Congressional Voting', American Journal of Political Science, 35:1, 228-78.

Putnam, Robert D. (1988). 'Diplomacy and Domestic Politics: The Logic of Two-Level Games', International Organization, 42:3, 427-60.

Rathbun, Brian C. (2004). Partisan Interventions: European Party Politics and Peace Enforcement in the Balkans. Ithaca, NY: Cornell University Press.

Raunio, Tapio (2014). 'Legislatures and Foreign Policy', in Shane Martin, Thomas Saalfeld, and Kaare W. Strøm (eds.), The Oxford Handbook of Legislative Studies. Oxford: Oxford University Press, 543-66.

Raunio, Tapio (2016). 'Refusing to be sidelined: the engagement of the Finnish Eduskunta in foreign affairs', Scandinavian Political Studies DOI: 10.1111/1467-9477.12071. 
Rozenberg, Olivier, Chopin, Olivier, Hoeffler, Catherine, Irondelle, Bastien, and Joana, Jean (2011). 'Not Only a Battleground: Parliamentary Oral Questions Concerning Defence Policies in Four Western Democracies', Journal of Legislative Studies, 17:3, 340-53.

Rozenberg, Olivier, Chopin, Olivier, Hoeffler, Catherine, Irondelle, Bastien, and Joana, Jean (2015). 'Des députés experts militaires? Les motivations et rétributions au sien des commissions défense de parlements européens', Politique européenne, 48:2, 178-200.

Sakaki, Alexandra, and Lukner, Kerstin (2017). 'Japan's Uncertain Security Environment and Changes in its Legislative-Executive Relations', West European Politics.

Schelling, Thomas C. (1960). The Strategy of Conflict. Cambridge: Harvard University Press.

Schuster, Jürgen, and Maier, Herbert (2006). 'The Rift: Explaining Europe's Divergent Iraq Policies in the Run-up of the American-Led War on Iraq', Foreign Policy Analysis, 2:3, 223-44.

Scott, James M, and Carter, Ralph G. (2014). 'The Not-So-Silent Partner: Patterns of LegislativeExecutive Interaction in the War on Terror, 2001-2009', International Studies Perspectives, 15:2, 186-208.

Shugart, Matthew S. (2006). 'Comparative Executive-Legislative Relations', in R.A.W. Rhodes, Sarah A. Binder, and Bert A. Rockman (eds.), The Oxford Handbook of Political Institutions. Oxford: Oxford University Press, 344-65. 
Strøm, Kaare (1990). 'A Behavioral Theory of Competitive Political Parties', American Journal of Political Science, 34:2, 565-98.

Strøm, Kaare (2000). 'Delegation and accountability in parliamentary democracies', European Journal of Political Research, 37:3, 261-89.

Strøm, Kaare, Müller, Wolfgang C., and Bergman, Tornjörn eds. (2003). Delegation and Accountability in Parliamentary Democracies. Oxford: Oxford University Press.

Strøm, Kaare, Müller, Wolfgang C., and Bergman, Torbjörn eds. (2008). Cabinets and Coalition Bargaining: The Democratic Life Cycle in Western Europe. Oxford: Oxford University Press.

Strøm, Kaare, Müller, Wolfgang C., and Smith, Daniel Markham (2010). 'Parliamentary Control of Coalition Governments', Annual Review of Political Science, 13, 517-35.

Tilly, Charles, ed. (1975). The Formation of National States in Western Europe. Princeton: Princeton University Press.

Waever, Ole (1995). 'Securitization and Desecuritization', in Ronnie D. Lipschutz (ed.), On Security. New York: Columbia University Press, 46-86.

Wagner, Wolfgang, Herranz-Surrallés, Anna, Kaarbo, Juliet and Ostermann, Falk (2017). The Party Politics of Legislative-Executive Relations in Security and Defence Policy, West European Politics.

Wildavsky, Aaron (1966). 'The two presidencies', Trans-Action, 4:2, 7-14. 
Winzen, Thomas (2013). 'European Integration and National Parliamentary Oversight Institutions', European Union Politics, 14:2, 297-323.

Zürn, Michael (2014). 'The politicization of world politics and its effects: Eight propositions', European Political Science Review, 6:1, 47-71.

${ }^{1}$ As we focus on national legislative-executive relations, the European Parliament is not at the centre of attention in any of the papers in this collection. Interparliamentary cooperation and the international contacts of political parties and MPs are also mentioned only in those instances where they are relevant for understanding the role of domestic parliaments in foreign affairs. On interparliamentary networking, including in CFSP, see for example Costa et al. (2013), Crum and Fossum (2013), and Herranz-Surrallés (2014).

2 In the United States this argument has been strongly influenced by the thesis about 'two presidencies', initially proposed by Wildavsky (1966), with the president enjoying considerably more discretion in foreign affairs than in domestic matters.

3 An extension of this argument is that granting parliaments a say in foreign policy makes international bargaining more difficult: status quo bias in world politics increases when the role of the legislature and other domestic veto-players is more institutionalized. A counter-argument is that ex ante legislative engagement can contribute to the credibility of the negotiators and have a positive impact on the eventual implementation of the pacts (Martin 2000).

${ }^{4}$ The executive may utilize legislative veto as a bargaining chip in international negotiations. This feature is known as the 'Schelling Conjecture' (Schelling 1960), according to which an executive whose hands are tied by a domestic ratification constraint such as a parliamentary veto can negotiate more favourable outcomes than an unconstrained executive. However, it is nonetheless predominantly argued that the structural two-level games logic of international bargaining shields 
governments from parliamentary control. The executive branch can use international institutions to insulate themselves from parliaments and other domestic actors, and to push through or legitimize even unpopular reforms. (Putnam 1988; Evans et al. 1993; Milner 1997; Pahre 2006; Mansfield and Milner 2012)

5 The War Powers Resolution was intended to curb and constrain president's right to use force abroad, making sure that the executive consulted Congress and also gets its approval during military operations. No president has acknowledged the constitutionality of the resolution, and several presidents have disregarded it, including Barack Obama in 2011 when he did not seek Congressional approval for the attack on Libya, arguing that the resolution did not apply to that action. Many voices inside Congress have also argued that the resolution is too ambitious and goes too far — some issues are simply just better left to the executive, and the president needs a certain level of discretion for the efficient conduct of military operations.

${ }^{6}$ It was precisely this collective action aspect which made it so surprising when the Turkish Grand National Assembly refused to ratify the government's decision in March 2003 to permit the United States to use Turkey as an air base for its operations in Iraq (Kesgin and Kaarbo 2010).

${ }^{7}$ Government composition is also relevant, with coalitions arguably less likely to use force abroad than single-party cabinets (Auerswald and Saideman 2014; Mello 2014), although other research suggests that multi-party cabinets actually correlate positively with international commitments and conflictual behaviour (Clare 2010; Kaarbo 2012; Beasley and Kaarbo 2014). 